Original Article

\title{
High population levels lead Glycaspis brimblecombei (Hemiptera: Aphalaridae) to unrecorded feeding and oviposition behaviors on Eucalyptus urograndis plants
}

\author{
Altos níveis populacionais levam Glycaspis brimblecombei (Hemiptera: Aphalaridae) \\ a diferentes comportamentos de alimentação e oviposição em plantas de \\ Eucalyptus urograndis
}

\author{
M. H. F. A. Dal Pogetto ${ }^{a}$ (D, W. S. Tavares ${ }^{\text {b* }}$ (D) J. C. Zanuncioc (D), W. M. Silvad (D), M. V. Massone (D), \\ P. J. Ferreira-Filhof (D), L. R. Barbosag ${ }^{\text {(D) }}$ and C. F. Wilcken ${ }^{\mathrm{h}}$ (D) \\ ${ }^{a}$ Corteva Agriscience, Mogi Mirim R\&D Center, Mogi Mirim, SP, Brasil. \\ ${ }^{\mathrm{b}}$ Asia Pacific Resources International Holdings Ltd. - APRIL, PT. Riau Andalan Pulp and Paper - RAPP, Pangkalan Kerinci, Riau, Sumatra, \\ Indonesia \\ cUniversidade Federal de Viçosa - UFV, Departamento de Entomologia/BIOAGRO, Viçosa, MG, Brasil \\ dUniversidade Federal de Viçosa - UFV, Departamento de Engenharia Florestal, Viçosa, MG, Brasil \\ eBracell Ltd., Alagoinhas, BA, Brasil \\ fUniversidade Federal de São Carlos - UFSCar, Departamento de Ciências Ambientais, Sorocaba, SP, Brasil \\ ${ }^{\mathrm{g}}$ Embrapa Florestas, Colombo, PR, Brasil \\ "Universidade Estadual Paulista “Júlio de Mesquita Filho" - UNESP, Departamento de Proteção Vegetal, Botucatu, SP, Brasil
}

\begin{abstract}
The red gum lerp psyllid, Glycaspis brimblecombei Moore, 1964 (Hemiptera: Aphalaridae), an insect pest originating in Australia and which feeds only on Eucalyptus L'Hér. (Myrtales: Myrtaceae) plants, has spread to several countries. The populations of this insect commonly reach high populations on Eucalyptus plants since its entry into Brazil, and also indicated an unrecorded behavioral. The objectives of this study were to describe a peculiar adaptation in the feeding habit of G. brimblecombei and to register the new habit. The oviposition and feeding by G. brimblecombei, commonly, on the leaves of Eucalyptus, started to occur, also, on lignified twigs. This suggests a not yet recorded adaptation of this insect to reduce insect $\times$ plant intraspecific competition.
\end{abstract}

Keywords: intraspecific competition, insect behavior, Eucalyptus camaldulensis, eucalypt pest, red gum lerp psyllid.

\section{Resumo}

O psilídeo de concha, Glycaspis brimblecombei Moore, 1964 (Hemiptera: Aphalaridae), um inseto praga originário da Austrália e que se alimenta apenas de plantas de Eucalyptus L'Hér. (Myrtales: Myrtaceae), se espalhou por vários países. Esse inseto, geralmente, atinge grandes populações em plantas de Eucalyptus desde sua entrada no Brasil e, também, indicou um comportamento diferente. Os objetivos deste estudo foram descrever uma adaptação peculiar no hábito alimentar de G. brimblecombei e registrar o novo hábito. A oviposição e alimentação por G. brimblecombei, geralmente, nas folhas de Eucalyptus, passaram a ocorrer, também, em ramos lignificados. Isso sugere uma adaptação diferente desse inseto para reduzir a competição intraespecífica inseto × planta.

Palavras-chave: competição intraespecífica, comportamento dos insetos, Eucalyptus camaldulensis, praga do eucalipto, psilídeo de concha.

\section{Introduction}

The red gum lerp psyllid, Glycaspis brimblecombei Moore, 1964 (Hemiptera: Aphalaridae) is native to eastern Australia (Tuller et al., 2017; Yurt and Karaca, 2018) and feeds only on plants of the Eucalyptus L'Hér (Myrtales: Myrtaceae) genus (Petro et al., 2017; Jere et al., 2019). The $G$. brimblecombei prefers species from the river red

gum group, especially Eucalyptus camaldulensis Dehnh. (Brennan et al., 2001). However, it has adapted to other species of this genus, such as Eucalyptus blakelyi Maiden, Eucalyptus brassiana S.T. Blake, Eucalyptus bridgesiana R.T. Baker, Eucalyptus camphora R. Baker, Eucalyptus dealbata A. Cunn. ex Schauer, Eucalyptus

*e-mail: Wagner_Tavares@aprilasia.com; wagnermaias@yahoo.com.br

Received: April 11, 2021 - Accepted: December 22, 2021 
diversicolor F. Muell., Eucalyptus globulus Labill., Eucalyptus lehmannii (Schauer) Benth., Eucalyptus mannifera Mudie, Eucalyptus nicholii Maiden \& Blakely, Eucalyptus nitens (H. Deane \& Maiden) Maiden, Eucalyptus rudis Endl., Eucalyptus sideroxylon A. Cunn. ex Woolls, Eucalyptus tereticornis Sm., and Eucalyptus urophylla S.T. Blake (Moore, 1970; Brennan and Gill, 1999; Brennan et al., 2001).

Glycaspis brimblecombei is a pest with great potential for invasion, as reinforced by international agencies, including the Food and Agriculture Organization of the United Nations (FAO) (Reguia and Peris-Felipo, 2003; Ferreira-Filho et al., 2017; Mannu et al., 2018) and has spread across many different regions of the world (Valente and Hodkinson, 2009; Cuello et al., 2018). The countries with reports of $G$. brimblecombei include Algeria, Ethiopia, Madagascar, Mauritius, Morocco, South Africa, Tunisia, and Zambia, in Africa; Israel and Turkey in Asia; France, Greece, Italy, Montenegro, Portugal, and Spain in Europe; Mexico and the United States of America in North America; Australia and New Zealand in Oceania; Argentina, Brazil, Chile, Colombia, Ecuador, Peru, Uruguay, and Venezuela in South America (Burckhardt et al., 2008; Laudonia and Garonna, 2010; Malumphy et al., 2013; Bella and Rapisarda, 2013; Tsagkarakis et al., 2014; Attia and Rapisarda, 2014; Karaca et al., 2015; Bouvet et al., 2005; Chungu et al., 2017; Yirgu and Anjulo, 2019).

The area planted with Eucalyptus in Brazil was 7.5 million hectares in 2021, with an average productivity of $39 \mathrm{~m}^{3}$ per ha (Pavan et al., 2021; André et al., 2021). The entry of G. brimblecombei in Brazil, through the state of São Paulo in 2003 (Santana and Burckhardt, 2007), started to demand the adoption of control strategies, burdening the cost of this culture (Boavida et al., 2016; Dias et al., 2017). The cost of applying systemic insecticide to control of G. brimblecombei ranged from $R \$ 40.00$ to $R \$ 150.00$ per round in the state of Santa Catarina, Brazil in 2011 (Garcia et al., 2011). Nymphs and adults of this insect suck the sap causing discoloration, drying and leaf fall, and top dieback of Eucalyptus plants (Pereira et al., 2013). In addition, excrement (honeydew) from the initial feed of $G$. brimblecombei, which is rich in sugars, facilitates the development of sooty mildew by reducing the rate of photosynthesis and the development of the plant (Huerta et al., 2010; Spodek et al., 2015). Successive damage with high infestations of $G$. brimblecombei can cause the fall of 20 to $30 \%$ of the leaves and up to a $40 \%$ mortality rate of Eucalyptus plants (Laudonia et al., 2014; Ferreira-Filho et al., 2015).

Glycaspis brimblecombei lays eggs on the surface of the leaves, where their nymphs insert the stylets into the phloem directly through the sheath to feed (Perris-Felipo et al., 2011; Ribeiro et al., 2015), avoiding reaching the oil glands (Brennan and Weinbaum, 2001a). Younger nymphs introduce the stylet between mesophilic cells and those in the fifth stage use an intracellular route (Pereira et al., 2013) with greater survival, of adults on mature Eucalyptus leaves (Brennan and Weinbaum, 2001a, b). Glycaspis brimblecombei reproduces sexually, laying six to 45 eggs per leaf, preferably on those younger (Firmino-Winckler et al., 2009). The nymphs of $G$. brimblecombei use honeydew and other chemical components produced by Malpighian tubules to build their cone-shaped covers (lerp), for protection, on the leaf surface (Sharma et al., 2013). Glycaspis brimblecombei has five instars, with a life cycle of 15 to 34 days and several generations per year in countries such as Brazil (Firmino-Winckler et al., 2009) and Italy (Laudonia et al., 2014).

The objectives of this study were to describe an unprecedented adaptation in the feeding habit of G. brimblecombei and to register the new habit.

\section{Methods and Materials}

\subsection{Experimental site}

The feeding habit of $G$. brimblecombei was examined on two-year-old clone hybrid plants of Eucalyptus urograndis (E. urophylla $\times$ E. grandis) in Bom Despacho, state of Minas Gerais, Brazil ( $19^{\circ} 44^{\prime}$ S $\times 45^{\circ} 15^{\prime} \mathrm{O}, 768 \mathrm{~m}$ above sea level) and on one year old E. camaldulensis clone plants in Luiz Antônio, state of São Paulo, Brazil ( $21^{\circ} 33^{\prime} \mathrm{S} \times 47^{\circ} 42^{\prime} \mathrm{O}$, $638 \mathrm{~m}$ above sea level). The damage by G. brimblecombei was compared between two groups of plants: this insect, only, on leaves (a) or on lignified leaves and twigs (b). Two stands, each with a group of plants "a" or "b", were examined per municipality. The average area per stand was 40 ha. The distance between stands in the same municipality was 1.0 and $2.0 \mathrm{Km}$ in Bom Despacho and Luiz Antônio, respectively. The damage was observed from July to September 2018 and 2019, months of the greatest occurrence of this pest in Brazil, due to the low intensity of rain and relative humidity (Masson et al., 2009; Oliveira et al., 2012; Silva et al., 2013). No control method was applied in the plantations since 30 days before and during the evaluation period. All photographs were taken using an HP Photosmart 945 - 5 megapixel digital camera, $8 \times$ zoom (Palo Alto, California, United States of America).

\subsection{Population density}

The population density of G. brimblecombei was evaluated by sampling 100 leaves per plant ( 20 plants per municipality, 10 plants per stand, randomly selected within them) in the middle third of the crown (Oliveira et al., 2012; Boavida et al., 2016), with leaf collection, manually, using a ladder. One collection was carried out per month per year of evaluation.

\section{Results}

\subsection{Population density}

The population density of G. brimblecombei was high in both municipalities, with more than 100 nymphs per Eucalyptus leaf (Figure 1A).

\subsection{Unrecorded feeding and oviposition habits}

Unrecorded feeding behavior and oviposition of G. brimblecombei were seen during the observation period of this insect in the field. This insect oviposited and nymphs 

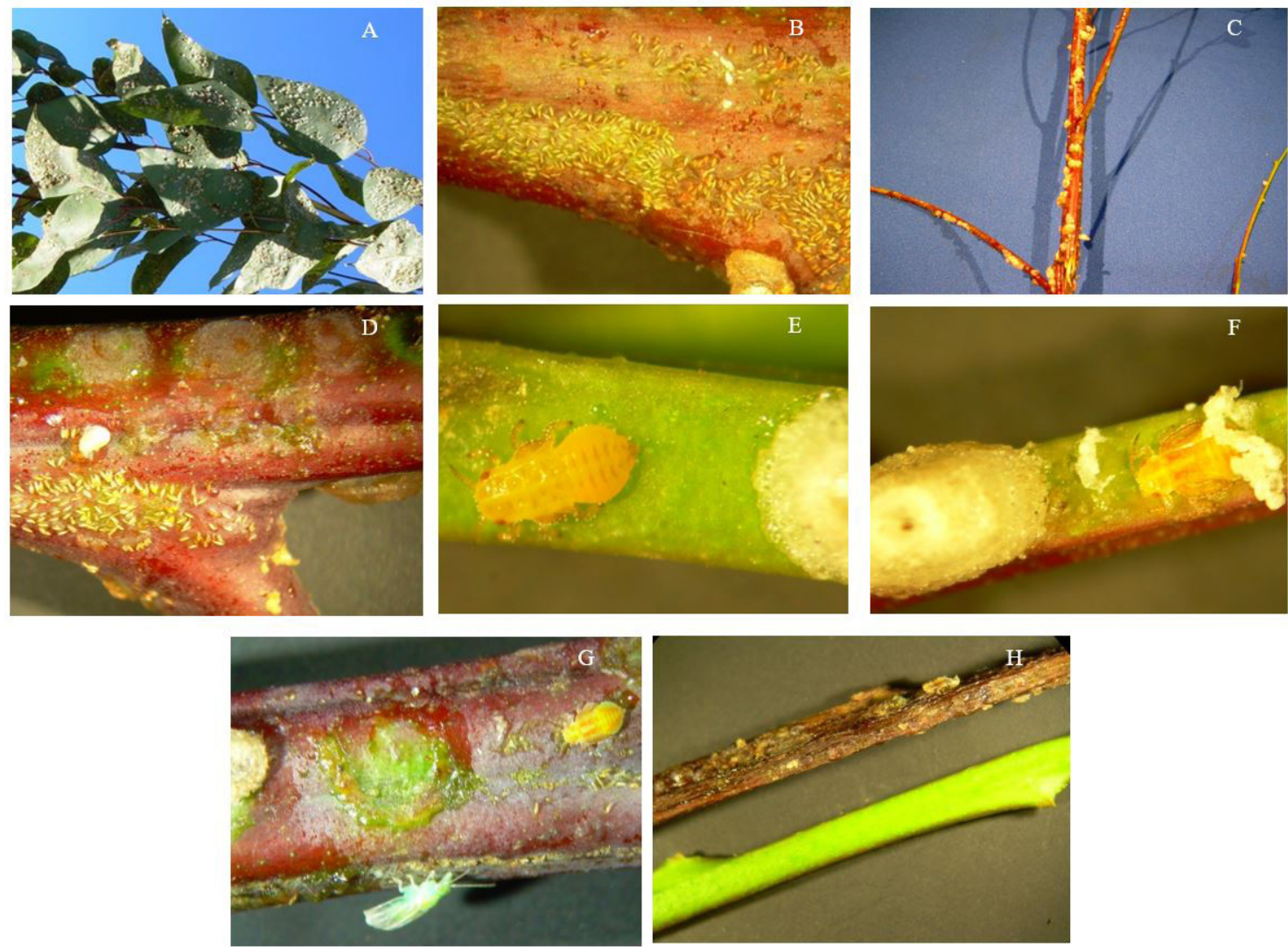

Figure 1. Glycaspis brimblecombei (Hemiptera: Aphalaridae) infestation with more than 100 nymphs per leaf of two-year-old Eucalyptus urograndis (Eucalyptus urophylla $\times$ Eucalyptus grandis) (Myrtales: Myrtaceae) in Bom Despacho, state of Minas Gerais, Brazil (A); eggs (B), lerps (C) and lerps marks (D) indicating feeding by the nymphs; fourth (E) and fifth (F) instar nymphs feeding on the lignified twigs after the manual removal of their shells; fifth instar nymphs and newly-formed G. brimblecombei adult $(\mathrm{G})$; healthy twig compared to a dry twig due to damage by $\mathrm{G}$. brimblecombei $(\mathrm{H})$.

were observed feeding on lignified twigs of plants of both E. camaldulensis and E. urograndis clones (Figures 1B-1F). The presence of adults on these twigs indicates that G. brimblecombei completed its cycle on this plant part (Figure 1G). Leaf fall was more pronounced from plants with a high population density of $G$. brimblecombei (i.e. insects on leaves and lignified twigs), with drying of the entire twig (twig dieback) and a greater reduction on the emission of new leaves by the plants (Figure $1 \mathrm{H}$ ), than in those with damage, by this pest, which was restricted to the leaves.

\section{Discussion}

Reports that adults and nymphs of $G$. brimblecombei feed only on leaf tissue are common (Perris-Felipo et al., 2011; Pereira et al., 2013; Ribeiro et al., 2015). The population of G. brimblecombei, in plantations of $E$. camaldulensis and E. urograndis, severely damaged by this pest (i.e. nymphs on leaves and lignified twigs) had a drastic reduction, after an intense leaf fall at the end of the dry season, probably due to food depletion and that herbivores feeding only on a plant genus are more sensitive to changes in the food availability (Steinbauer et al., 2016). Feeding by hemipterans on lignified twigs requires more energy to produce a greater amount of allelochemical detoxifying enzymes. The feeding on phloem suggests a high potential for these enzymes to bind to the $\mathrm{Ca}^{++}$of this plant vascular tissue to make sugars as food available to hemipterans (Sharma et al., 2014). In addition, the association of Aphalaridae species with endosymbiont bacteria induces changes in plant tissues. These bacteria and enzymes, like the pectinases in these insect salivary glands, allow them to mobilize primary metabolites quickly (Sharma and Raman, 2017).

The high density of $G$. brimblecombei, from the beginning to the end of the dry season, may have been due to the abundance of food, the low population of its parasitoid, Psyllaephagus bliteus Riek, 1962 (Hymenoptera: Encyrtidae) and the non-application of insecticides. This parasitoid was found, for the first time in Brazil, in 2003 in Piracicaba, state of São Paulo, shortly after the detection of G. brimblecombei (Berti Filho et al., 2003). However, its population has remained low in the field in Brazil (Ferreira-Filho et al., 2008; Silva et al., 2013; Ferreira-Filho et al., 2017).

The adaptation of feeding site in the same host by G. brimblecombei is apparently due to the reduction of its favorite food, as the damage by this insect was greater on 
the abaxial surface of E. camaldulensis and on the adaxial surface of the E. urophylla $\times$ E. camaldulensis and E. urophylla $\times E$. grandis hybrids. This was attributed to the ability of this insect to tolerate physical and chemical defenses due to the long coexistence with E. camaldulensis in Australia and to the greater flow of nutrients and its low desiccation on the abaxial surface (Firmino-Winckler et al., 2009; Tuller et al., 2017).

The uncommon adaptation in the feeding habit of G. brimblecombei in the present study was similar to that reported for the syzygium leaf psyllid, Trioza eugeniae Froggatt, 1901 (Hemiptera: Triozidae), which moved from the abaxial part of the plants, preferred for feeding, to the adaxial in conditions of greater intraspecific competition with Sygygium paniculatum Gaertn. (Myrtales: Myrtaceae) (Luft and Paine, 1997). Factors such as water stress (common in the Brazilian midwest region during winter) and/or genetic improvement of plants (production of Eucalyptus hybrids susceptible to the pest with branch morphology that allows them to feed), in addition to competition, may have contributed to the adaptation in feeding behavior by G. brimblecombei.

The adaptation in the feeding site, by nymphs of G. brimblecombei, from the leaves to lignified twigs, seems to be more drastic than those of other hemipteran, mainly due to the difference in hardness and rigidity between the tissues of leaves and twigs of the Eucalyptus. An adaptation of feeding location has also been reported for the soybean pests, Dichelops melacanthus (Dallas, 1851), Euschistus heros (F., 1798), Nezara viridula (L., 1758) (Hemiptera: Pentatomidae), and Neomegalotomus parvus (Westwood, 1842)(Hemiptera: Alydidae) that prefer seeds and fruits, but in the absence of this resource they feed on vegetative tissues (Panizzi, 2000). Empoasca fabae (Harris, 1841) (Hemiptera: Cicadellidae) feeds on twigs of the alfalfa plants, Medicago sativa L. (Fabales: Fabaceae), but migrates to the petiole and, later, to the leaves of this plant, the least preferred place for feeding, in highly infested genotypes or with high trichome density (Shockley et al., 2002).

The high susceptibility of E. camaldulensis and E. urograndis plants and favorable climatic conditions for the development of $G$. brimblecombei may facilitate the population increase of this pest. This insect, in high populations, also uses alternative resources and reproduces and develops on the lignified twigs of the plants of these species.

\section{Acknowledgements}

We are grateful to "Conselho Nacional de Desenvolvimento Científico e Tecnológico (CNPq)", "Coordenação de Aperfeiçoamento de Pessoal de Nível Superior (CAPES)", "Fundação de Amparo a Pesquisa do Estado de Minas Gerais (FAPEMIG)", and "Programa Cooperativo sobre Proteção Florestal (PROTEF)" of the "Instituto de Pesquisas e Estudos Florestais (IPEF)" for their financial support. The English of the final version was revised by Adam Batten from Get It Right in Jakarta, Indonesia.

\section{References}

ANDRÉ, J.L., OLIVEIRA, R., SETTE JUNIOR, C.R., ALFENAS, A.C., ZAUZA, E.Â.V., SIQUEIRA, L. and NOVAES, E., 2021. Wood volume of Eucalyptus clones established under different spacings in the Brazilian Cerrado. Forest Science, vol. 67, no. 4, pp. 478-489. http://dx.doi.org/10.1093/forsci/fxab016.

ATTIA, S.B. and RAPISARDA, C., 2014. First record of the red gum lerp psyllid, Glycaspis brimblecombei Moore (Hemiptera: Psyllidae), in Tunisia. Phytoparasitica, vol. 42, no. 1, pp. 535-539. http:// dx.doi.org/10.1007/s12600-014-0391-8.

BELLA, S. and RAPISARDA, C., 2013. First record from Greece of the invasive red gum lerp psyllid Glycaspis brimblecombei Moore (Hemiptera: Psyllidae) and its associated parasitoid Psyllaephagus bliteus Riek (Hymenoptera: Encyrtidae). Redia, vol. 96, no. 1, pp. 33-35.

BERTI FILHO, E., COSTA, V.A., ZUPARKO, R.L. and LA SALLE, J., 2003. Occurrence of Psyllaephagus bliteus Riek (Hymenoptera: Encyrtidae) in Brazil. Revista de Agricultura, vol. 78, no. 3, pp. 304. http://dx.doi.org/10.37856/bja.v78i3.301.

BOAVIDA, C., GARCIA, A. and BRANCO, M., 2016. How effective is Psyllaephagus bliteus (Hymenoptera: Encyrtidae) in controlling Glycaspis brimblecombei (Hemiptera: Psylloidea)? Biological Control, vol. 99, no. 1, pp. 1-7. http://dx.doi.org/10.1016/j. biocontrol.2016.04.003.

BOUVET, J.P.R., HARRAND, L. and BURCKHARDT, D., 2005. First record of Blastopsylla occidentalis and Glycaspis brimblecombei (Hemiptera: Psyllidae) from Argentina. Revista de la Sociedad Entomológica Argentina, vol. 64, no. 1-2, pp. 99-102.

BRENNAN, E.B. and GILL, R.J., 1999. First record of Glycaspis brimblecombei (Moore) (Homoptera: Psyllidae) in North America: Initial observations and predator associations of a potentially serious new pest of Eucalyptus in California. The Pan-Pacific Entomologist, vol. 75, no. 1, pp. 55-57.

BRENNAN, E.B. and WEINBAUM, S.A., 2001a. Performance of adult psyllids in no-choice experiments on juvenile and adult leaves of Eucalyptus globulus. Entomologia Experimentalis et Applicata, vol. 100, no. 2, pp. 179-185. http://dx.doi.org/10.1046/j.15707458.2001.00862.x.

BRENNAN, E.B. and WEINBAUM, S.A., 2001b. Stylet penetration and survival of three psyllid species on adult leaves and 'waxy' and 'de-waxed' juvenile leaves of Eucalyptus globulus. Entomologia Experimentalis et Applicata, vol. 100, no. 3, pp. 355-363. http:// dx.doi.org/10.1046/j.1570-7458.2001.00883.x.

BRENNAN, E.B., HRUSA, G.F., WEINBAUM, S.A. and LEVISON JUNIOR, W., 2001. Resistance of Eucalyptus species to Glycaspis brimblecombei (Homoptera: Psyllidae) in the San Francisco Bay area. The Pan-Pacific Entomologist, vol. 77, no. 4, pp. 249-253.

BURCKHARDT, D., LOZADA, P.W. and DIAZ, W.D., 2008. First record of the red gum lerp psyllid Glycaspis brimblecombei (Hemiptera: Psylloidea) from Peru. Mitteilungen der Schweizerische Entomologische Gesellschaft, vol. 81, no. 1-2, pp. 83-85. http:// dx.doi.org/10.5169/seals-402960.

CHUNGU, D., SHAKACITE, O., CHAMA, H., CHUNGU, B.C., MBINDO, K. and MULONGWE, L., 2017. First record of the red gum lerp psyllid, Glycaspis brimblecombei Moore (Hemiptera: Psyllidae), in Zambia. African Journal of Ecology, vol. 55, no. 3, pp. 380-382. http://dx.doi.org/10.1111/aje.12353.

CUELLO, E.M., LÓPEZ, S.N., ANDORNO, A.V., HERNÁNDEZ, C.M. and BOTTO, E.N., 2018. Development of Glycaspis brimblecombei Moore (Hemiptera: Aphalaridae) on Eucalyptus camaldulensis Dehnh. and Eucalyptus dunnii Maiden. Agricultural and Forest Entomology, vol. 20, no. 1, pp. 73-80. http://dx.doi.org/10.1111/ afe.12230. 
DIAS, T.K.R., PIRES, E.M., WILCKEN, C.F., SOUZA, A.P., SOLIMAN, E.P. and SILVA, C.C., 2017. The psilid Glycaspis brimblecombei in transition areas Biomes Amazon and Brazilian Savanna. Acta Brasiliensis, vol. 1, no. 1, pp. 19-22. http://dx.doi.org/10.22571/ Actabra11201710.

FERREIRA-FILHO, P.J., WILCKEN, C.F., OLIVEIRA, N.C., DAL POGETTO, M.H.F.A. and LIMA, A.V.C., 2008. Spatial distribution of red gum lerp psyllid, Glycaspis brimblecombei (Hemiptera: Psyllidae) and its parasitoid, Psyllaephagus bliteus (Hymenoptera: Encyrtidae) population in Eucalyptus camaldulensis plantation. Boletin de Sanidad Vegetal, Plagas, vol. 34, no. 1, pp. 11-20.

FERREIRA-FILHO, P.J., WILCKEN, C.F., LIMA, A.C.V., SÁ, L.A.N., CARMO, J.B., GUERREIRO, J.C. and ZANUNCIO, J.C., 2015. Biological control of Glycaspis brimblecombei (Hemiptera: Aphalaridae) in eucalyptus plantations. Phytoparasitica, vol. 43, no. 1, pp. 151-157. http://dx.doi.org/10.1007/s12600-014-0440-3.

FERREIRA-FILHO, P.J., WILCKEN, C.F., MASSON, M.V., TAVARES, W.S., GUERREIRO, J.C., CARMO, J.B., PRADO, E.P. and ZANUNCIO, J.C., 2017. Influence of temperature and rainfall on the population dynamics of Glycaspis brimblecombei and Psyllaephagus bliteus in Eucalyptus camaldulensis plantations. Revista Colombiana de Entomologia, vol. 43, no. 1, pp. 1-6. http://dx.doi.org/10.25100/ socolen.v43i1.6638.

FIRMINO-WINCKLER, D.C., WILCKEN, C.F., OLIVEIRA, N.C. and MATOS, C.A.O., 2009. Red gum lerp psyllid Glycaspis brimblecombei Moore (Hemiptera, Psylidae) biology in Eucalyptus spp. Revista Brasileira de Entomologia, vol. 53, no. 1, pp. 144-146. http:// dx.doi.org/10.1590/S0085-56262009000100030.

GARCIA, F.R.M., SAVARIS, M. and PEREIRA, D.V.M., 2011. First record of the parasitoids Psyllaephagus bliteus Riek (Hymenoptera: Encyrtidae) in the Santa Catarina State, Brazil. Biodiversidade Pampeana, vol. 9, no. 1, pp. 61-63.

HUERTA, A., FAÚNDEZ, M. and ARAYA, J.E., 2010. Susceptibility of Eucalyptus spp. to an induced infestation of red gum lerp psyllid Glycaspis brimblecombei Moore (Hemiptera: Psyllidae) in Santiago, Chile. Ciencia e Investigación Agraria, vol. 37, no. 2, pp. 27-33. http://dx.doi.org/10.4067/S0718-16202010000200003.

JERE, V., MHANGO, J., NJERA, D. and JENYA, H., 2019. Infestation of Glycaspis brimblecombei (Hemiptera: Psyllidae) on three Eucalyptus species in selected ecological zones in Malawi. African Journal of Ecology, vol. 58, no. 2, pp. 251-259. http:// dx.doi.org/10.1111/aje.12686.

KARACA, I., KAYAHAN, A., ŞIMŞEK, B. and ÇELIKPENÇE, Y., 2015. First record of Glycaspis brimblecombei Moore (Hemiptera: Aphalaridae), in Turkey. Phytoparasitica, vol. 43, no. 2, pp. 171175. http://dx.doi.org/10.1007/s12600-015-0457-2.

LAUDONIA, S. and GARONNA, A.P., 2010. The red gum lerp psyllid, Glycaspis brimblecombei, a new exotic pest of Eucalyptus camaldulensis in Italy. Bulletin of Insectology, vol. 63, no. 2, pp. 233-236.

LAUDONIA, S., MARGIOTTA, M. and SASSO, R., 2014. Seasonal occurrence and adaptation of the exotic Glycaspis brimblecombei Moore (Hemiptera: Aphalaridae) in Italy. Journal of Natural History, vol. 48, no. 11-12, pp. 675-689. http://dx.doi.org/10.1 080/00222933.2013.825021.

LUFT, P.A. and PAINE, T.D., 1997. Evaluation of environmental and plant-associated cues for nymphal settling preference by Trioza eugeniae. Entomologia Experimentalis et Applicata, vol. 85, no. 2, pp. 105-111. http://dx.doi.org/10.1046/j.1570-7458.1997.00240.x.

MALUMPHY, C., PEROVIĆ, T., HRNČIĆ, S., RADONJIĆ, S. and RAIČEVIĆ, M., 2013. First records of Acizzia jamatonica (Kuwayama) and Glycaspis brimblecombei Moore, (Hemiptera: Psyllidae,
Aphalaridae) in Montenegro. Acta Entomologica Serbica, vol. 18, no. 1-2, pp. 11-16.

MANNU, R., BUFFA, F., PINNA, C., DEIANA, V., SATTA, A. and FLORIS, I., 2018. Preliminary results on the spatio-temporal variability of Glycaspis brimblecombei (Hemiptera Psyllidae) populations from a three-year monitoring program in Sardinia (Italy). Redia, vol. 101, no. 1, pp. 107-114. http://dx.doi.org/10.19263/ REDIA-101.18.14.

MASSON, M.V., MATOS, W.C., SILVA, A.G.P., ALVES, J.M., RIBEIRO, G.T. and WILCKEN, C.F., 2009. Occurrence and population distribution of red gum lerp psyllid Glycaspis brimblecombei Moore 1964, (Hemiptera: Psyllidae) in eucalyptus forests in the North coast of Bahia State, Brazil. Boletin de Sanidad Vegetal, Plagas, vol. 35, no. 3, pp. 559-562.

MOORE, K.M., 1970. The Glycaspis spp. (Hemiptera: Psyllidae) Eucalyptus camaldulensis associations. Journal of the Australian Entomological Society, vol. 7, no. 1, pp. 3-7.

OLIVEIRA, K.N., JESUS, F.M., SILVA, J.O., ESPÍRITO-SANTO, M.M. and FARIA, M.L., 2012. An experimental test of rainfall as a control agent of Glycaspis brimblecombei Moore (Hemiptera, Psyllidae) on seedlings of Eucalyptus camaldulensis Dehn (Myrtaceae). Revista Brasileira de Entomologia, vol. 56, no. 1, pp. 101-105. http://dx.doi.org/10.1590/S0085-56262012005000008.

PANIZZI, A.R., 2000. Suboptimal nutrition and feeding behavior of hemipterans on less preferred plant food sources. Anais da Sociedade Entomológica do Brasil, vol. 29, no. 1, pp. 1-12. http:// dx.doi.org/10.1590/S0301-80592000000100001.

PAVAN, B.E., AMARAL, R.G., PUPIN, S., COSTA, R.M.L., DIAS, D., SCARPINATI, E.A. and PAULA, R.C., 2021. Competitive ability among Eucalyptus spp. commercial clones in Mato Grosso do Sul state. Forest Ecology and Management, vol. 494, pp. 119297. http://dx.doi.org/10.1016/j.foreco.2021.119297.

PEREIRA, J.M., BALDIN, E.L.L., SOLIMAN, E.P. and WILCKEN, C.F., 2013. Attractiveness and oviposition preference of Glycaspis brimblecombei Moore in Eucalyptus spp. Phytoparasitica, vol. 41, no. 1, pp. 117-124. http://dx.doi.org/10.1007/s12600-012-0268-7.

PERRIS-FELIPO, F.J., MANCUSI, G., TURRISI, G.F. and JIMÉNEZPEYDRÓ, R., 2011. New corological and biological data of the red gum lerp psyllid, Glycaspis brimblecombei Moore, 1964 in Italy (Hemiptera, Psyllidae). Biodiversity Journal, vol. 2, no. 1, pp. 13-17.

PETRO, R., MPIRI, A. and MKUDE, A., 2017. Susceptibility of Eucalyptus species and clones to red gum lerp psyllid, Glycaspis brimblecombei, (Hemiptera: Psyllidae) in Mbizi Forest Plantation, Tanzania. International Journal of Environment, Agriculture and Biotechnology, vol. 2, no. 1, pp. 417-420. http://dx.doi. org/10.22161/ijeab/2.1.52.

REGUIA, K. and PERIS-FELIPO, F.J., 2003. Glycaspis brimblecombei Moore, 1964 (Hemiptera Psyllidae) invasion and new records in the Mediterranean area. Biodiversity Journal, vol. 4, no. 4, pp. 501-506.

RIBEIRO, Z.A., SOUZA, B.H.S., COSTA, E.N., MENDES, J.E.P., MAFIA, R.G. and BOIÇA JÚNIOR, A.L., 2015. Glycaspis brimblecombei Moore, 1964 (Hemiptera: Psyllidae) on eucalyptus: Oviposition non-preference and antibiosis. Euphytica, vol. 202, no. 1, pp. 285-295. http://dx.doi.org/10.1007/s10681-014-1298-7.

SANTANA, D.L. and BURCKHARDT, D., 2007. Introduced Eucalyptus psyllids in Brazil. Journal of Forest Research, vol. 12, no. 1, pp. 337-344. http://dx.doi.org/10.1007/s10310-007-0035-7.

SHARMA, A. and RAMAN, A., 2017. Feeding biology and nutritional physiology of Psylloidea (Insecta: Hemiptera): Implications in host-plant relations. Current Science, vol. 113, no. 8, pp. 1543-1552. http://dx.doi.org/10.18520/cs/v113/i08/1543-1552. 
SHARMA, A., KHAN, A.N., SUBRAHMANYAM, S., RAMAN, A., TAYLOR, G.S. and FLETCHER, M.J., 2014. Salivary proteins of plantfeeding hemipteroids - implication in phytophagy. Bulletin of Entomological Research, vol. 104, no. 2, pp. 117-136. http:// dx.doi.org/10.1017/S0007485313000618. PMid:24280006.

SHARMA, A., RAMAN, A., TAYLOR, G. and FLETCHER, M., 2013. Nymphal development and lerp construction of Glycaspis sp. (Hemiptera: Psylloidea) on Eucalyptus sideroxylon (Myrtaceae) in central-west New South Wales, Australia. Arthropod Structure \& Development, vol. 42, no. 6, pp. 551-564. http://dx.doi. org/10.1016/j.asd.2013.07.005. PMid:23948315.

SHOCKLEY, F.W., BACKUS, E.A., ELLERSIECK, M.R., JOHNSON, D.W. and MCCASLIN, M., 2002. Glandular-haired alfalfa resistance to potato leafhopper (Homoptera: Cicadellidae) and hopperburn: development of resistance indices. Journal of Economic Entomology, vol. 95, no. 2, pp. 437-447. http://dx.doi. org/10.1603/0022-0493-95.2.437. PMid:12020025.

SILVA, A.L., PERES-FILHO, O., DORVAL, A. and CASTRO, C.K.C., 2013. Population dynamics of Glycaspis brimblecombei and natural enemies in Eucalyptus spp. in Cuiaba, state of Mato Grosso, Brazil. Floresta e Ambiente, vol. 20, no. 1, pp. 80-90. http:// dx.doi.org/10.4322/floram.2012.066.

SPODEK, M., BURCKHARDT, D., PROTASOV, A. and MENDEL, Z., 2015. First record of two invasive eucalypt psyllids (Hemiptera: Psylloidea) in Israel. Phytoparasitica, vol. 43, no. 2, pp. 401-406. http://dx.doi.org/10.1007/s12600-015-0465-2.
STEINBAUER, M.J., FARNIER, K., TAYLOR, G.S. and SALMINEN, J.P., 2016. Effects of eucalypt nutritional quality on the Bog gum-Victorian metapopulation of Ctenarytaina bipartita and implications for host and range expansion. Ecological Entomology, vol. 41, no. 2, pp. 211-225. http://dx.doi.org/10.1111/een.12295.

TSAGKARAKIS, A.E., KALAITZAKI, A.P. and BALOTIS, G.N., 2014. Note on Glycaspis brimblecombei Moore (Hemiptera Psyllidae): a new pest of Eucalyptus in Greece. Advances in Entomology, vol. 2, no. 1, pp. 57-59. http://dx.doi.org/10.4236/ae.2014.21010.

TULLER, J., OLIVEIRA, K.N., SILVA, J.O., FARIA, M.L., ESPÍRITOSANTO, M.M., SERRÃO, J.E. and ZANUNCIO, J.C., 2017. Glycaspis brimblecombei (Hemiptera: Psyllidae) attack patterns on different Eucalyptus genotypes. PeerJ, vol. 5, no. 3864, e3864. http://dx.doi.org/10.7717/peerj.3864. PMid:29085744.

VALENTE, C. and HODKINSON, I., 2009. First record of the red gum lerp psyllid, Glycaspis brimblecombei Moore (Hem.: Psyllidae), in Europe. Journal of Applied Entomology, vol. 133, no. 4, pp. 315-317. http://dx.doi.org/10.1111/j.1439-0418.2008.01324.x.

YIRGU, A. and ANJULO, A., 2019. First record of Glycaspis brimblecombei Moore (Hem.: Psyllidae) on Eucalyptus camaldulensis in Ethiopia. Phytoparasitica, vol. 47, no. 1, pp. 67-70. http://dx.doi.org/10.1007/s12600-018-00711-0.

YURT, N.T. and KARACA, İ., 2018. Population development of Glycaspis brimblecombei (Hemiptera: Aphalaridae) on Eucalyptus camaldulensis and beneficial species in this area. Journal of Natural and Applied Sciences, vol. 22, pp. 83-88. https://doi. org/10.19113/sdufbed.57606. 